\title{
PENERAPAN TRANSIT ORIENTED DEVELOPMENT (TOD) SEBAGAI UPAYA MEWUJUDKAN TRANSPORTASI YANG BERKELANJUTAN
}

\author{
Sekar Hapsari Ayuningtias ${ }^{1}$ \\ Mila Karmilah ${ }^{2}$ \\ Program Studi Perencanaan Wilayah dan Kota Universitas Islam Sultan Agung \\ Penulis Korespondensi e-mail: sekarayuningtias26@gmail.com
}

\begin{abstract}
Urban sprawl causes the lifestyle of private vehicle use as the main preference in the choice of transportation modes which results in congestion, air pollution and energy use in the transportation sector which continues to increase. Transit Oriented Development (TOD) is an alternative solution in solving these problems, with the concept of urban development that maximizes diverse and integrated land use by promoting healthy lifestyles through walking and cycling and maximizing the use of mass transportation modes. Therefore, this research was conducted with the aim of knowing the application of the development of TOD for planning to achieve sustainable transportation.

The variables used in this study are density, diversity, design and transit which are a combination of the theories of Cervero (1997) and ITDP (2014). The results of the study showed that the city of Surabaya was dominated by transit, Bandung Cit $y$ and Jakarta City variables which were both dominated by density and transit variables. Based on inter-case studies there are differences between indicators theory and indicators case study, and each case study also has different parameters. Thus, there has been an adjustment in the theory of the application of TOD in Indonesia, besides that the indicators of TOD implementation are also adjusted according to the characteristics and policies of the region concerned
\end{abstract}

Keywords: TOD, sustainable, transport

\begin{abstract}
ABSTRAK
Urban sprawl menyebabkan terjadinya gaya hidup penggunaan kendaraan pribadi sebagai preferensi utama dalam pemilihan moda transportasi yang berakibat pada kemacetan, pencemaran udara dan penggunaan energi pada sektor transportasi yang terus meningkat. Transit Oriented Development (TOD) merupakan salah satu solusi alternatif dalam menyelesaikan permasalahan tersebut, dengan konsep pengembangan kota yang memaksimalkan penggunaan lahan beragam dan terintegrasi dengan mempromosikan gaya hidup sehat melalui berjalan kaki dan bersepeda serta memaksimalkan penggunaan moda transportasi massal. Oleh sebab itu, penelitian ini dilakukan dengan tujuan untuk mengetahui penerapan pengembangan TOD bagi perencanaan guna mencapai transportasi yang berkelanjutan.

Variabel yang digunakan dalam penelitian ini adalah density, diversity, design dan transit yang merupakan gabungan dari teori Cervero (1997) dan ITDP (2014). Hasil penelitian menunjukkan bahwa Kota Surabaya didominasi dengan variabel transit, Kota Bandung dan Kota Jakarta sama-sama didominasi oleh variabel density dan transit. Berdasarkan kajian antar studi kasus terdapat perbedaan antara indikator teori dan indikator studi kasus, dan masing-masing studi kasus juga memiliki parameter yang berbeda pula. Sehingga, terjadi penyesuaian teori penerapan TOD di Indonesia, selain itu indikator penerapan TOD juga disesuaikan sesuai dengan karakteristik dan kebijakan kawasan yang bersangkutan.

Kata kunci: TOD, transportasi, berkelanjutan
\end{abstract}




\section{Pendahuluan}

Perkembangan kota-kota diseluruh dunia mengalami perkembangan yang sangat cepat, salah satunya disebabkan oleh adanya aktivitas urbanisasi. Urbanisasi menyebabkan kota kota menjadi padat akan penduduk, tingginya aktivitas yang terjadi meningkatkan pergerakan manusia didalamnya serta terjadinya pemekaran atau berkembangnya kawasan perkotaan. Meluasnya kawasan perkotaan dengan berkembangan kawasan pinggiran sebagai alternatif lokasi hunian bagi masyarakat merupakan residu dari efek padatnya sebuah kota, masyarakat akan terus terdesak hingga keluar dari wilayah inti perkotaan menunuju ke pinggiran kota atau disebut sebagai Urban Sprawl (Kusumantoro, 2007).

Pada konteks pembangunan berkelanjutan, Urban Sprawl dianggap sebagai salah satu pembawa efek buruk bagi suatu daerah, salah satunya adalah gaya hidup yang memungkinkan penggunaan kendaraan pribadi sebagai pilihan transportasi utama bagi masyarakat yang tinggal dikawasan pinggiran kota. Penggunaan kendaraan pribadi sebagai alat transportasi utama bagi masyarakat pinggiran kota dapat memberikan dampak negatif, salah satunya peningkatan mobilitas yang berpengaruh kepada terciptanya kemacetan lalu lintas disuatu wilayah.

Permasalahan Urban Sprawl telah lama menjadi fokus bagi para perencana, untuk mengatasi permasalahan tersebut, Peter Calthorpe, seorang Arsitek Perencana berkebangsaan Amerika memperkenalkan sebuah konsep TOD (Transit-Oriented Development) untuk mengatasi permasalahan Urban Sprawl. TOD sendiri didefinisikan sebagai penggunaan lahan campuran, kota dengan kepadatan yang relative tinggi, serta pengembangan yang berorientasi kepada pejalan kaki di sekitar stasiun kereta api atau bus (Staricco, 2017). TOD memiliki tujuan guna merivitalisasi daerah dengan mempromosikan gaya hidup yang baru, yakni gaya hidup sehat, nyaman dan aman.

Pesatnya perkembangan kawasan pinggiran seolah menjadi momok tersendiri bagi berbagai kebijakan penataan ruang. Dalam konteks pembangunan berkelanjutan, Urban Sprawl dianggap sebagai salah satu pembawa efek buruk bagi suatu daerah, salah satunya adalah gaya hidup yang memungkinkan penggunaan kendaraan pribadi sebagai pilihan transportasi utama bagi masyarakat yang tinggal dikawasan pinggiran kota. Penggunaan kendaraan pribadi sebagai alat transportasi utama bagi masyarakat pinggiran kota dapat memberikan dampak negatif, salah satunya peningkatan mobilitas yang berpengaruh kepada terciptanya kemacetan lalu lintas disuatu wilayah. Tindakan tindakan yang diambil dalam mengatasi permasalahan kota-kota berkembang umumnya masih terpaku pada 
permasalahan sektoral dan internal kota, seperti permasalahan kemiskinan perkotaan, kawasan permukiman kumuh, ketersediaan air bersih, sanitasi lingkungan dan persoalan internal kota lainya, sehingga masalah perkembangan kawasan pinggiran relatif kurang tersentuh (Kusumantoro, 2007).

Kota-kota di negara-negara Benua Eropa dan Amerika telah terlebih dahulu mengimplementasikan konsep TOD sebagai salah satu elemen penyelesaian permasalahan Urban Sprawl dan dijadikan dasar dalam pembentukan kota yang berkelanjutan. Konsep ini diyakini dapat menjadikan kota lebih Kompak dan terintegrasi antara sisitem transportasi dengan guna lahan perkotaan. Baru-baru ini, beberapa pemerintah kota di negara-negara Asia seperti Hongkong, Taiwan, China, Korea sudah mulai mengkaji penerapan konsep TOD untuk mengatasi permasalahan perkotaan mereka terutama kemacetan lalu lintas.

Menurut Cervero (1993), secara ideal kawasan TOD memiliki tiga aspek yaitu density, diversity dan design. Density berkaitan dengan kepadatan kawasan atau intensitas pemanfaatan lahan yang tinggi, diversity berkaitan dengan keberagaman penggunaan lahan dan jenis aktivitas pada kawasan dan design berkaitan dengan desain kawasan yang ramah terhadap pejalan kaki dan pesepeda.

Beberapa kota di Indonesia sudah menerapkan sistem TOD dalam mengintegrasi sistem transportasi yang berkelanjutan. Terlebih, diterbitkannya Peraturan Menteri ATR/BPN RI No. 16 Tahun 2017 tentang Pedoman Pengembangan Kawasan Berorientasi Transit, yang menandakan Pemerintah Indonesia akan menerapkan konsep TOD dalam perencanaan transportasi negeri ini. Selain itu, terdapat kota-kota di Indonesia yang menerapkan sistem BRT (Bus Rapid Transit) yang merupakan salah satu unsur penerapan TOD. Kepemilikian BRT di suatu kota merupakan suatu embrio dalam penerapan TOD. Dengan adanya TOD, diharapkan kota-kota di Indonesia dapat mengatasi permasalahan seperti urban sprawl, peningkatan aksesibilitas dan mobilitas sehingga kemacetan akan berkurang, mereduksi pencemaran lingkungan serta efisiensi penggunaan energi pada sektor transportasi, mengurangi ketergantungan terhadap penggunaan kendaraan pribadi sehingga mencapai sistem transportasi yang berkelanjutan dan kota-kota tersebut dapat lebih berkembang dengan baik. Sudah sepatutnya saat ini mengupayakan sebuah pendekatan perencanaan spasial yang inovatif dan mampu mengakomodir mobilitas penduduk dengan sistem transit transportasi yang terintegrasi dan berkelanjutan. Berdasarkan latar belakang yang telah dijelaskan, maka perlu dilakukan bagaimana potensi 
penerapan konsep TOD dengan mengidentifikasi studi kasus lain dengan teori yang relevan, dikarenakan TOD berpotensi untuk diterapkan di kota-kota di seluruh Indonesia sebagai solusi alternatif dalam mengatasi permasalahan kota, bentuk inovasi pembangunan wilayah dan kota dan mencapai sistem transportasi yang berkelanjutan.

\section{Kajian Pustaka}

\subsection{Transit Oriented Development (TOD)}

Transit Oriented Development (TOD) merupakan konsep pengembangan atau pembangunan kota yang memaksimalkan penggunaan lahan yang bercampur dan terintegrasi dengan mempromosikan gaya hidup yang sehat (berjalan kaki dan bersepeda) dan penggunaan angkutan umum massal (TOD guidebook, 2006)

Tabel 1 Variabel/Indikator TOD

\begin{tabular}{|c|c|}
\hline Sumber & Variabel/Indikator \\
\hline \multirow[t]{5}{*}{ Calthrope (1993) } & $\begin{array}{l}\text { 1. Public Transportation } \\
\text { (Terminal Transportasi) }\end{array}$ \\
\hline & 2. Publoc Uses/Space (Ruang Publik) \\
\hline & $\begin{array}{l}\text { 3. Core Commercial (Pusat Area } \\
\text { Komersil) }\end{array}$ \\
\hline & 4. $\quad$ Residential Area (Area Permukiman) \\
\hline & 5. Secondary Area (Area Sekunder) \\
\hline \multirow[t]{3}{*}{ Cervero (1997) } & 1. Density (Kepadatan) \\
\hline & 2. Diversity (Keberagaman) \\
\hline & 3. Design (Desain Kawasan) \\
\hline \multirow{8}{*}{$\begin{array}{l}\text { ITDP (Institure for } \\
\text { Transportation and } \\
\text { Development Policy); } \\
2014\end{array}$} & 1. Walk (Berjalan kaki) \\
\hline & 2. Cycle (Bersepeda) \\
\hline & 3. Connect (Berhubungan) \\
\hline & 4. $\quad$ Transit (Angkutan Umum) \\
\hline & 5. Mix (Bercampur) \\
\hline & 6. Densify (Memadatkan) \\
\hline & 7. Compact (Kompak) \\
\hline & 8. Shift (Beralih) \\
\hline
\end{tabular}

Sumber: Penulis, 2019

\subsection{Sistem Transportasi}

Sistem transportasi merupakan bentuk interaksi antara penumpang, barang, sarana serta prasarana untuk bergerak atau berpindah dengan tujuan tertentu yang mencangkup dalam tatanan alami maupun buatan (Aziz\&Asrul, 2014).

\subsection{Transportasi Berkelanjutan}

Transportasi berkelanjutan merupakan sistem transportasi yang dapat digunakan secara efektif, efisien, mereduksi emisi yang tidak meninggalkan masalah dan tidak 
menimbulkan dampak negatif dimasa yang akan datang, serta memiliki tiga pilar yaitu ekonomi, sosial, dan lingkungan (Brotodewo, 2010).

Tabel 2 Indikator Transportasi yang Berkelanjutan

\begin{tabular}{|c|c|c|}
\hline Aspek & Deskripsi & Kriteria \\
\hline Ekonomi & $\begin{array}{l}\text { Mengupayakan pelayanan sistem transportasi } \\
\text { yang dapat menunjang kegiatan ekonomi } \\
\text { khususnya di perkotaan dengan meningkatkan } \\
\text { aksesbilitas wilayah dan menciptakan } \\
\text { transportasi yang produktif efisien }\end{array}$ & $\begin{array}{l}\text { - Aksesibilitas yang baik } \\
\text { - Transportasi yang produktif } \\
\text { - Aktivitas transportasi yang } \\
\text { efisien } \\
\text { - Moda split: perjalanan } \\
\text { dengan berjalanan kaki, } \\
\text { bersepeda atau angkutan } \\
\text { masal }\end{array}$ \\
\hline Sosial & $\begin{array}{l}\text { Mengupayakan adanya kesetaraan antara } \\
\text { masyarakat secara vertikal maupun horizontal } \\
\text { dalam pelayanan transportasi dan terdapatnya } \\
\text { kelembagaan-kelembagaan yang menunjang } \\
\text { sistem transportasi berkelanjutan dengan } \\
\text { kebijakan partisipasi masyarakat }\end{array}$ & $\begin{array}{l}\text { - Pelayanan transportasi yang } \\
\text { setara } \\
\text { - Tingkat keselamatan, } \\
\text { keamanan yang tinggi } \\
\text { - Aktivitas transportasi yang } \\
\text { dapat meningkatkan kualitas } \\
\text { masyarakat untuk bergerak } \\
\text { tanpa kendaraan } \\
\text { - Adanya sistem kelembagaan } \\
\text { yang menunjang transportasi } \\
\text { berkelanjutan }\end{array}$ \\
\hline Lingkungan & $\begin{array}{l}\text { Mengupayakan penggunaan sumberdaya } \\
\text { seminimal mungkin untuk kepentingan kini } \\
\text { dan mendatang, serta menciptakan } \\
\text { lingkungan yang nyaman tanpa dampak } \\
\text { negatif dari aktivitas transportasi }\end{array}$ & $\begin{array}{l}\text { - Seimbangnya penggunaan } \\
\text { sumberdaya pada kegiatan } \\
\text { transportasi } \\
\text { - Minimnya pencemaran } \\
\text { lingkungan yang disebabkan } \\
\text { oleh transportasi } \\
\text { - Perlindungan habitat }\end{array}$ \\
\hline
\end{tabular}

Sumber: Brotodewo, 2010

\subsection{Landasan Teori}

Variabel yang digunakan merupakan variabel yang dicetuskan oleh Cervero (1997) yaitu Density, Diversity dan Design dan transit (angkutan umum) yang dicetuskan oleh ITDP (2014) karena variabel tersebut sudah menggambarkan seluruh prinsip utama dalam penerapan TOD secara lebih singkat, untuk selengkapnya dapat dilihat pada tabel berikut:

Tabel 3 Keterkaitan Antar Variabel TOD dan Transportasi Berkelanjutan

\begin{tabular}{|c|c|c|c|c|}
\hline Variabel & Sumber & Penjelasan Singkat & $\begin{array}{c}\text { Keterkaitan } \\
\text { dengan teori } \\
\text { Cervero (1997) }\end{array}$ & $\begin{array}{c}\text { Aspek } \\
\text { Transportasi } \\
\text { Berkelanjutan }\end{array}$ \\
\hline Tern & \multirow{4}{*}{$\begin{array}{l}\text { Calthorpe } \\
\text { (1997) }\end{array}$} & \multirow{4}{*}{$\begin{array}{l}\text { Tersedianya titik } \\
\text { transit, Ruang terbuka, } \\
\text { Pusat permukiman dan } \\
\text { fasilitas umum yang } \\
\text { terintegrasi dan dapat } \\
\text { dijangkau dengan } \\
\text { berjalan kaki }\end{array}$} & \multirow{4}{*}{$\begin{array}{l}\text { Diversity } \\
\text { (Penggunaan lahan } \\
\text { atau jenis aktivitas } \\
\text { yang bercampur } \\
\text { membuat } \\
\text { masyarakat tidak } \\
\text { menggunakan }\end{array}$} & \multirow{4}{*}{$\begin{array}{l}\text { Ekonomi, Sosial } \\
\text { (Penggunaan lahan } \\
\text { yang beragam akan } \\
\text { memotong biaya } \\
\text { perjalanan dan dapat } \\
\text { meningkatkan } \\
\text { kualitas masyarakat }\end{array}$} \\
\hline $\begin{array}{l}\text { Ruang } \\
\text { Terbuka }\end{array}$ & & & & \\
\hline $\begin{array}{l}\text { Pusat } \\
\text { Permukim }\end{array}$ & & & & \\
\hline $\begin{array}{l}\text { Fasilitas } \\
\text { Umum }\end{array}$ & & & & \\
\hline
\end{tabular}




\begin{tabular}{|c|c|c|c|c|}
\hline Variabel & Sumber & Penjelasan Singkat & $\begin{array}{c}\text { Keterkaitan } \\
\text { dengan teori } \\
\text { Cervero (1997) } \\
\end{array}$ & $\begin{array}{c}\text { Aspek } \\
\text { Transportasi } \\
\text { Berkelanjutan } \\
\end{array}$ \\
\hline & & & kendaraan pribadi) & $\begin{array}{l}\text { dalam } \\
\text { bersosialisasi) }\end{array}$ \\
\hline $\begin{array}{l}\text { Berjalan kaki } \\
\text { (walk) }\end{array}$ & \multirow[t]{8}{*}{$\begin{array}{l}\text { ITDP } \\
(2014)\end{array}$} & \multirow{2}{*}{$\begin{array}{l}\text { Sebagai transportasi } \\
\text { un-motorized untuk } \\
\text { mengurangi } \\
\text { permasalahan }\end{array}$} & \multirow{3}{*}{ 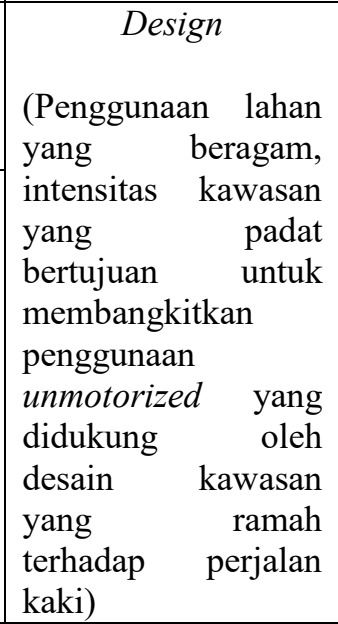 } & \multirow{3}{*}{\begin{tabular}{l}
\multicolumn{1}{c}{ Ekonomi, } \\
\multicolumn{1}{c}{ Lingkungan } \\
(Penggunaan \\
kendaraan \\
unmotorized atau \\
berjalan kaki dapat \\
mengurangi biaya \\
transportasi ran \\
berdampak pada \\
keberlanjutan \\
lingkungan karena \\
minimnya polusi \\
udara dan suara)
\end{tabular}} \\
\hline $\begin{array}{l}\text { Bersepeda } \\
\text { (cycle) }\end{array}$ & & & & \\
\hline Beralih (Shift) & & \begin{tabular}{l}
\multicolumn{2}{c|}{ Perpindahan } \\
mobilitas dari \\
kendaraan bermotor \\
menjadi berjalan \\
kaki/bersepeda.
\end{tabular} & & \\
\hline $\begin{array}{l}\text { Berhubungan } \\
\text { (Connect) }\end{array}$ & & \begin{tabular}{lrr}
\multicolumn{2}{c}{ Adanya } & \multicolumn{2}{c}{ integrasi } \\
antar & jalan & dan \\
jaringan & jalan & yang \\
padat & &
\end{tabular} & \begin{tabular}{lr}
\multicolumn{2}{c}{ Design } \\
(Desain & kawasan \\
TOD & merupakan \\
desain & kawasan \\
yang & ramah \\
terhadap & pejalan \\
kaki & yang \\
terintegritas & dengan \\
waktu tempuh yang \\
singkat)
\end{tabular} & \begin{tabular}{lr}
\multicolumn{1}{c}{ Ekonomi, } \\
\multicolumn{1}{c}{ Lingkungan } \\
(Penggunaan \\
kendaraan \\
unmotorized \\
berjalan kaki dapat \\
mengurangi biaya \\
transportasi r dan \\
berdampak pada \\
lingkungan karena \\
minimnya polusi \\
udara dan suara)
\end{tabular} \\
\hline $\begin{array}{l}\text { Angkutan } \\
\text { umum } \\
\text { (Transit) }\end{array}$ & & $\begin{array}{l}\text { Penggunaan moda } \\
\text { transportasi massal } \\
\text { untuk perjalanan yang } \\
\text { cukup jauh. }\end{array}$ & - & - \\
\hline $\begin{array}{l}\text { Pencampuran } \\
\text { (Mix) }\end{array}$ & & $\begin{array}{r}\text { Penggunaan lahan } \\
\text { yang kompak, }\end{array}$ & $\begin{array}{l}\text { Diversity dan } \\
\text { Density }\end{array}$ & $\begin{array}{c}\text { Ekonomi, } \\
\text { Lingkungan }\end{array}$ \\
\hline $\begin{array}{l}\text { Memadatkan } \\
\text { (Densify) }\end{array}$ & & $\begin{array}{lr}\text { bervariasi } & \text { dan } \\
\text { memiliki } & \text { intensitas }\end{array}$ & (Penggunaan lahan & (Penggunaan \\
\hline $\begin{array}{l}\text { Kompak } \\
\text { (Compact) }\end{array}$ & & $\begin{array}{l}\text { yang tinggi dapat } \\
\text { membuat masyarakat } \\
\text { tidak menggunakan } \\
\text { kendaraan pribadi }\end{array}$ & $\begin{array}{lr}\text { yang } & \text { bercampur } \\
\text { dengan } & \text { jenis } \\
\text { kegiatan } & \text { yang } \\
\text { bervariasi } & \text { serta } \\
\text { intensitas } & \\
\text { pemanfaatan } & \text { lahan } \\
\text { yang padat } & \text { dapat } \\
\text { membuat } & \text { suatu } \\
\text { kawasan } & \text { menjadi } \\
\text { kompak, sehingga } \\
\text { penggunaan } \\
\text { kendaraan } & \text { pribadi }\end{array}$ & $\begin{array}{l}\text { kendaraan } \\
\text { unmotorized atau } \\
\text { berjalan kaki dapat } \\
\text { mengurangi biaya } \\
\text { transportasi ran } \\
\text { berdampak pada } \\
\text { keberlanjutan } \\
\text { lingkungan karena } \\
\text { minimnya polusi } \\
\text { udara, suara dan } \\
\text { penggunaan bahan } \\
\text { energi }\end{array}$ \\
\hline
\end{tabular}




\begin{tabular}{|l|l|l|l|l|}
\hline Variabel & Sumber & Penjelasan Singkat & $\begin{array}{c}\text { Keterkaitan } \\
\text { dengan teori } \\
\text { Cervero (1997) }\end{array}$ & $\begin{array}{c}\text { Aspek } \\
\text { Transportasi } \\
\text { Berkelanjutan }\end{array}$ \\
\hline & & $\begin{array}{l}\text { dapat diminimalisir } \\
\text { dan mendorong } \\
\text { masyarakat untuk } \\
\text { berjalan kaki atau } \\
\text { bersepeda karena } \\
\text { jika suatu kawasan } \\
\text { kompak, dan padat } \\
\text { maka jarak yang } \\
\text { ditempuh juga } \\
\text { sedikit) }\end{array}$ \\
\hline
\end{tabular}

Sumber: Penulis, 2019

\section{Hasil Dan Pembahasan}

Analisis penerapan konsep TOD dilakukan dengan melihat studi kasus sesuai dengan review literatur yang telah dilakukan, berikut merupakan hasilnya:

\subsection{Kota Surabaya}

Meningkatnya penggunaan kendaraan pribadi pada ruas-ruas jalan utama menyebabkan kemacetan di Surabaya. Hal tersebut dapat diidentifikasi melalui kemampuan kapasistas jalan menunjukkan nilai melebihi 0,5-0,8 sehingga menunjukkan volume lalu lintas yang tinggi dan melebihi kapasitas yang seharusnya (Handayeni\&Ariantia, 2014). Sehingga, pengembangan moda transportasi massal cepat direncakan dengan harapan kemacetan dapat direduksi melalui pengalihan penggunaan moda pribadi ke moda transportasi umum.

Penyelesaian kemacetan dilakukan dengan upaya pengembangan angkutan umum massal cepat berbasis monorail dan tremway yang akan menuntut masyarakat beralih ke moda transportasi umum. Berdasarkan hasil studi yang dilakukan Sung dan Oh (2012), pengalihan penggunaan kendaraan ke angkutan publik dipengaruhi oleh desain kawasan disekitar lokasi transit yang berarti integrase perencanaan kawasan sekitar lokasi transit perencanaan jaringan dan sarana transportasi perlu direncanakan dan dikembangkan.

Penerapan TOD merupakan suatu konsep yang mengedepankan integrasi antara ciri kawasan di sekitar titik transit dengan sistem jaringan transit yang menghubunginya, sehingga dapat mendorong penggunaan sistem transit dan mengurangi penggunaan moda pribadi (Isa, 2016). Oleh karena itu, perlu diperhatikan bagaimana pengembangan kawasan berbasis TOD yang dapat mempengaruhi perubahan perilaku berkendara untuk meminimalisir permasalahan kemacetan perkotaan. Keberhasilan penerapan TOD di 
negara-negara Asia, Eropa dan Amerika dapat menjadi best practice dalam mengatasi kemacetan di Kota Surabaya dengan adanya kebijakan yang mengarahkan pergerakan transit melalui pengembangan angkutan umum massal sehingga terwujud keberlanjutan transportasi di Kota Surabaya (Ramadhani dan Sardjito, 2017)

\subsubsection{Aspek Transit Oriented Development (TOD)}

Berdasarkan variabel terpilih terkait TOD, yaitu diversity, density, design dan transit berikut merupakan aspek TOD di Kota Surabaya

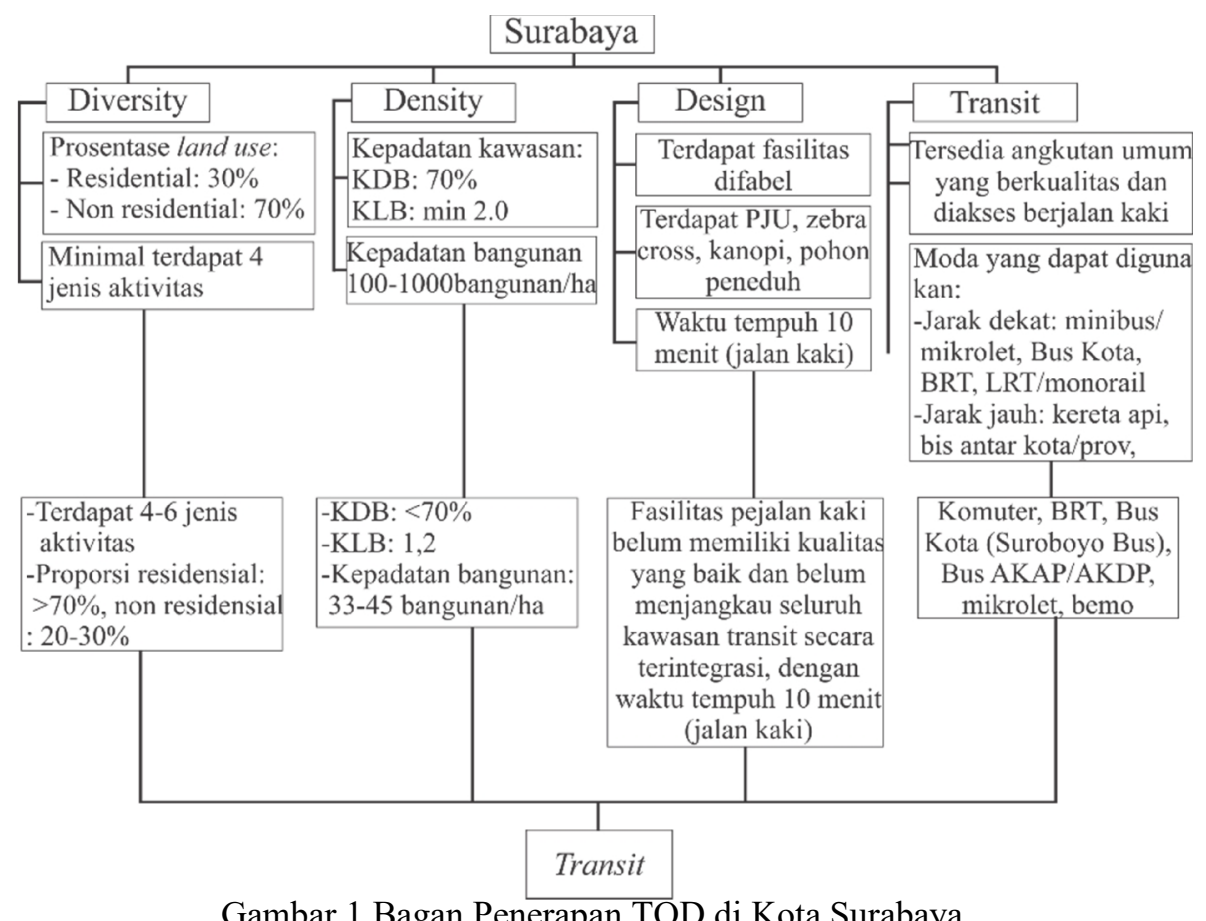

Gambar 1 Bagan Penerapan TOD di Kota Surabaya

Sumber: Penulis, 2019

Berdasarkan varibel diversity, terdapat indikator yang telah ditetapkan yakni prosentasi penggunaan lahan residensial sebesar 30\% non residensial sebesar $70 \%$ serta minimal terdapat 4 jenis aktivitas. Pada kondisi eksisting, terdapat 4-6 jenis aktivitas pada kawasan transit dengan proporsi residensial $>70 \%$ dan non residensial $20-30 \%$. Pada variabel density, indikator yang ditetapkan adalah intensitas pemanfaaatan lahan kawasan dengan KDB 70\%, KLB minimal 2 dan kepadatan bangunan 100-1000 bangunan/ha, dan pada kondisi eksisting KDB kawasan adaah $<70 \%$, KLB 1,2 dan kepadatan bangunan: 3345 bangunan/ha. Variabel design ditetapkan indikator yakni berupa kualitas pedestrian yang aman dan nyaman dengan adanya fasilitas difabel, terdapat PJU, zebracross, kanopi, pohon peneduh serta waktu tempuh ke pusat kegiatan selama 10 menit dengan berjalan kaki. Pada kondisi eksisting, fasilitas pejalan kaki belum memiliki kualitas yang baik dan 
belum menjangkau seluruh kawasan transit secara terintegrasi, dengan waktu tempuh 10 menit (jalan kaki). Sedangkan variabel transit dengan indikator tersedianya angkutan umum yang berkualitas dan diakses dengan berjalan kaki, dan pada kondisi eksisting, Kota Surabaya terdapat berbagai moda transportasi umum berupa komuter, BRT, Bus Kota (Suroboyo Bus), Bus AKAP/AKDP, mikrolet dan bemo.

Penerapan kawasan transit berkonsep TOD di Kota Surabaya diatas, Kota Surabaya didominasi oleh variabel transit (angkutan umum), pada kondisi eksisting terdapat banyak stasiun dan terminal beserta moda transportasi umumnya, seperti kereta komuter, BRT, Suroboyo Bus, mikrolet dan bemo untuk jarak dekat sedangkan untuk jarak jauh terdapat Bus AKAP/AKDP. Perencanaan sistem transportasi Kota Surabaya sudah merujuk TOD dengan merencanakan monorail/LRT, mendesain jalur pejalan kaki agar nyaman dan aman sehingga jumlah pejalan kaki dapat meningkat untuk selengkapnya dapat dilihat pada diangram berikut

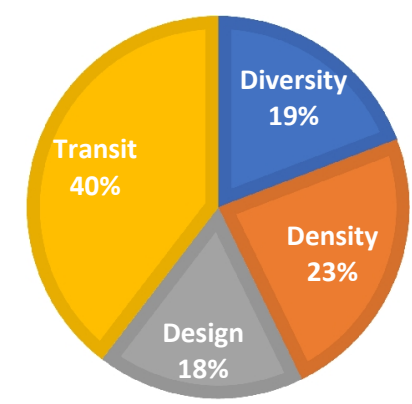

Gambar 2 Diagram Prosentasi Variabel TOD di Kota Surabaya Sumber: Hasil Analisis, 2019

\subsection{Kota Bandung}

Kawasan perkotaan Bandung terjadi suburbanisasi yang diakibatkan pertumbuhan jumlah penduduk dan keterbatasan lahan yang berujung pada persoalan transportasi. Kawasan perkotaan Bandung memiliki daya tarik sebagai tujuan perjalanan dan akumulasi berbagai aktivitas ekonomi, pemerintah, sosial dan budaya serta membangkitkan pergerakan komuter dari kawasan pinggiran menuju kawasan perkotaan. Hal tersebut memberikan dampak negatif pada pergerakan lalulintas kawasan sebagai akibat dari tidak tersedianyya inftrastruktur transportasi yang efektif dan dapat mengakomodasi mobilitas masyarakat di kawasan perkotaan Bandung (Widyahari\&Indradjati, 2015). Untuk mengurangi beban lalu lintas, perlu pembangunan yang diarahkan untuk menciptakan sistem transportasi yang lebih efisien dan berkelanjutan sehingga mampu mendorong 
terciptanya mobilitas dan aksesbilitas kegiatan masyarakat dengan baik. Hal tersebut dapat dilakukan dengan pengintegrasian terhadap konsep pengembangan perkotaan untuk mengatasi gejala urban sprawl dan ketergantungan penduduk terhadap penggunaan kendaraan pribadi, yaitu dengan menerapkan pengembangan kawasan berbasis TOD. Berkenaan dengan perencanaan pembangunan Kota Bandung dengan konsep live, work, and play (kehidupan, pekerjaan dan wisata/hiburan), perencanaan konsep struktur ruang kota Bandung mendatang akan diarahkan pada pola polisentrik yang diharapkan akan menumbuhkan perkembangan Kota Bandung menuju compact city atau pertumbuhan kota yang terpadu dan teratur (BUMP, 2013).

\subsubsection{Aspek Transit Oriented Development (TOD)}

Penerapan TOD pada kawasan transit di Kota Bandung dibedakan menjadi dua, yaitu regional center dan urban center, untuk selengkapnya dapat dilihat pada grafik berikut

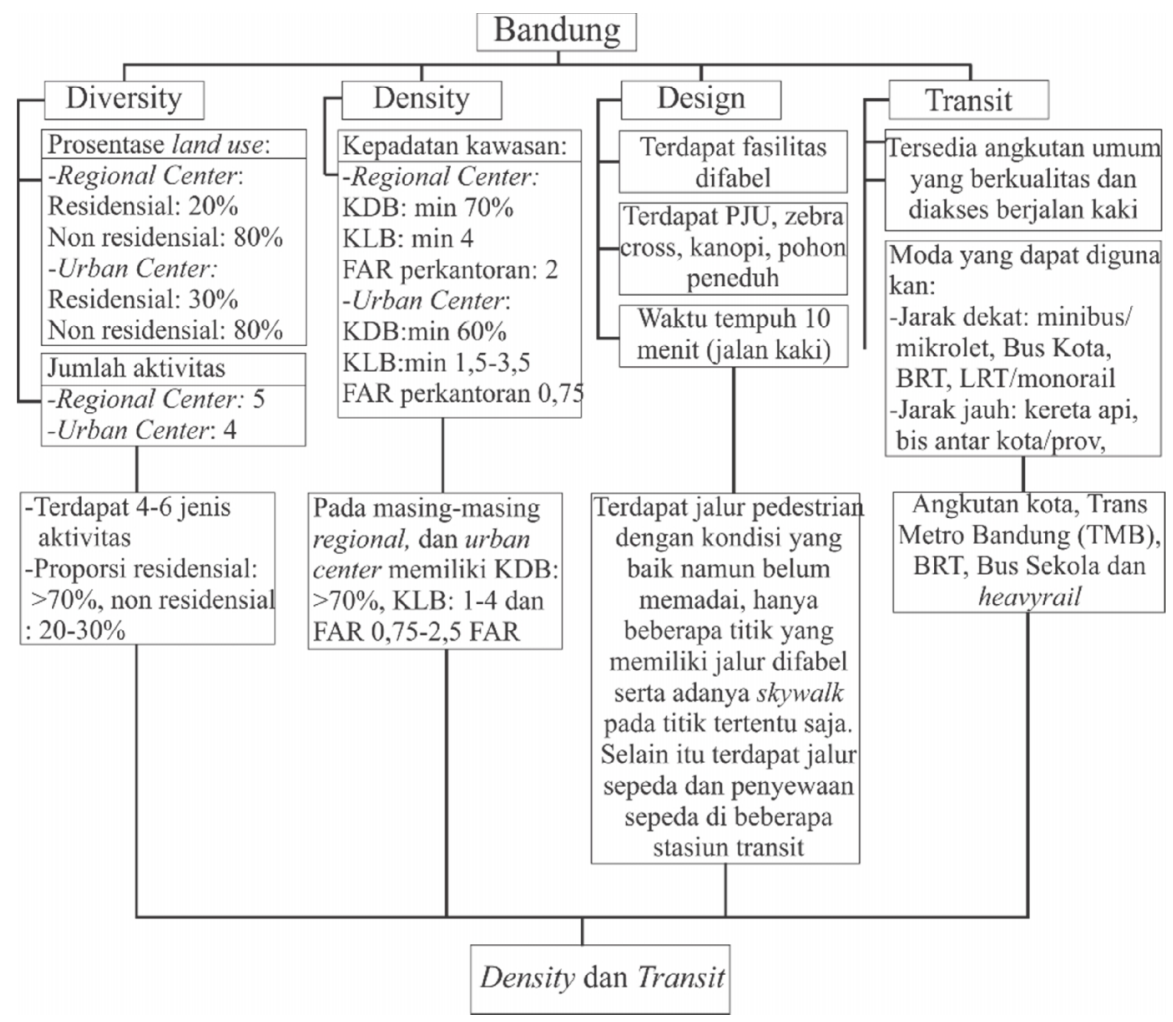

Gambar 3 Bagan Penerapan TOD di Kota Bandung Sumber: Penulis, 2019

Variabel diversity (keberagaman) pada TOD di Kota Bandung memiliki indikator prosentase penggunan lahan pada regional center yaitu $20 \%$ residensial dan $80 \%$ non residensial, sedangkan pada urban center yaitu 30\% residensial dan $70 \%$ non residensial 
dan jumlah aktivitas pada regional center yaitu minimal 5 aktivitas sedangkan jumlah aktivitas pada urban center berjumlah minimal 4 aktivitas. Pada kondisi eksisting Kota Bandung memiliki 4-6 jenis aktivitas dengan proporsi residensial $>70 \%$ dan non residensial 20-30\%. Variabel density (kepadatan) kawasan memiliki indikator pada regional center dengan kriteria intensitas pemanfaatan kawasan KDB $\geq 70 \%$, KLB $\geq 4$ dan FAR perkantoran $\geq 2$ sedangkan pada urban center $\mathrm{KDB} \geq 60 \%$, KLB 1,5-3,5 dan FAR perkantoran $\geq 0,75$. Pada masing-masing regional maupun urban center di kondisi eksisting, KDB kawasan sebesar $>70 \%$ dengan KLB 1-4 dan FAR 0,75-2,5. Variabel design kawasan di Kota Bandung memiliki indikator dengan tujuan untuk melihat kualitas dari jalur pejalan kaki yakni dengan tersedianya fasilitas difabel, PJU, zebracross, kanopi dan pohon peneduh serta waktu tempuh dari kawasan transit ke pusat aktivitas selama 10 menit. Pada kondisi eksisting kawasan transit di Kota Bandung sudah memiliki jalur pedestrian dengan kondisi yang baik namun kuantitasnya belum memadai, hanya beberapa titik saya yang memiliki jalur difabel serta adanya skywalk pada titik tertentu saja. Selain itu sudah terdapat jalur sepeda dan penyewaan sepeda di beberapa stasiun transit. Sedangkan variabel transit dengan indikator tersedianya angkutan umum yang berkualitas dan diakses dengan berjalan kaki, dan pada kondisi eksisting, Kota Bandung memiliki berbagai moda transportasi umum berupa angkutan umum, Trans Metro Bandung (TMB), BRT, Bus Sekolah dan heavyrail.

Penerapan kawasan TOD di Kota Bandung didominasi oleh variabel density (kepadatan kawasan) dan transit (angkutan umum), dengan prosentase sebagai berikut

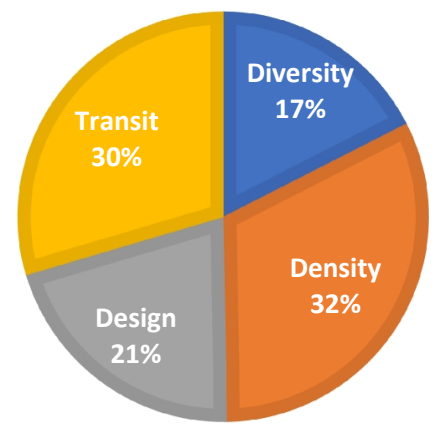

Gambar 4 Diagram Prosentasi Variabel TOD di Kota Bandung Sumber: Penulis, 2019

Pada kondisi eksisting, Kota Bandung memiliki banyak titik transit berupa stasiun (barang dan penumpang) serta terminal dengan moda transportasi berupa angkutan kota, 
Trans Metro Bandung, BRT dan Bus Sekolah untuk jarak dekat dan heavyrail untuk jarak jauh. Kepadatan kawasan disekitar titik transit juga memiliki kepadatan yang sudah melewati batas indikator, namun kepadatan kawasan masih berupa kepadatan horizontal, belum kepadatan vertikal. Variabel lainnya yaitu diversity dan design pada kondisi eksisting terus mengalami peningkatan karena TOD juga merupakan program kerja pemerintah dalam BUMP (Bandung Urban Mobility Project), selain itu salah satu stasiun di Kota Bandung dijadikan percontohan sebagai titik simpul strategis dan titik simpul sistem angkutan terintegrasi serta mendapat bantuan dari Kedutaan Besar Inggris melalui program Future Cities dan menjadi wakil Indonesia dari 19 negara yang dibantu kedubes Inggris (Mauludy, 2019)

\subsection{Kota Jakarta}

Sektor transportasi perkotaan memiliki berbagai tantangan yang disebabkan oleh peningkatan penduduk yang diprediksi nantinya sekitar dua-pertiga penduduk tersebut hidup dan beraktivitas di kawasan perkotaan yang akan memiliki pada kemacetan karena tingginya mobilitas penduduk (Arsyad\&Handayeni, 2018). Kota Jakarta merupakan salah satu kota metropolitan yang memiliki pertumbuhan penduduk yang signifikan setiap tahunnya (BPS,2017). Sebagai kota yang menjadi pusat kegiatan ekonomi dan pusat pemerintahan, menjadikan Jakarta memiliki pergerakan penduduk yang tinggi. Dalam melakukan aktivitasnya, masyarakat memiliki dua preferensi pemilihan moda transportasi, yakni menggunakan moda atau tanpa menggunakan moda. Moda transportasi yang digunakan dapat berupa moda transportasi pribadi dan moda transportasi massal. Sedangkan penduduk DKI Jakarta lebih memilih kendaraan pribadi sehingga timbul permasalahan lalu lintas seperti kemacetean, polusi udara dan sebagainya (BPS, 2016).

Permasalahan kemacetan tersebut dapat diminimalisir dengan cara mengalihkan orientasi penggunaan kendaraan pribadi ke angkutan massal berbasis transit yang sering disebut Transit Oriented Development (TOD). Konsep pembangunan berorientasi transit di Jakarta sudah tertuang dalam Raperda RTRW Provinsi DKI Jakarta 2030. Dalam peraturan tersebut dijelaskan bahwa TOD atau pengembangan berorientasi transit merupakan kawasan terpadu dari berbagai kegiatan fungsional kota dengan fungsi penghubung lokal dan antar lokal dengan konsep yang dijabarkan dalam pengaturan tentang Sistem Pusat Kegiatan (Alvinsyah, 2016)

Beberapa kawasan di wilayah DKI Jakarta yang direncanakan pengembangannya menerapkan konsep TOD, kawasan tersebut antara lain kawasan Dukuh Atas, Manggarai, 
Harmoni, Senen, Blok M dan Grogol (Siregar,2015). Kawasan-kawasan tersebut direncanakan sebagai stasiun terpadu dan titik perpindahan beberapa moda transportasi. Sistem prasarana TOD di DKI Jakarta dikembangkan pada terminal/stasiun antar moda pada pusat-pusat kegiatan, stasiun angkutan jalan rel, shelter angkutan massal jalan raya dan terminal angkutan umum jalan raya yang terintegrasi dengan pengembangan lahan disekitarnya supaya mencapai sistem transportasi yang berkelanjutan (Alvinsyah, 2016)

\subsubsection{Aspek Transit Oriented Development (TOD)}

Penerapan TOD pada kawasan transit di Kota Jakarta dapat dilihat pada grafik berikut

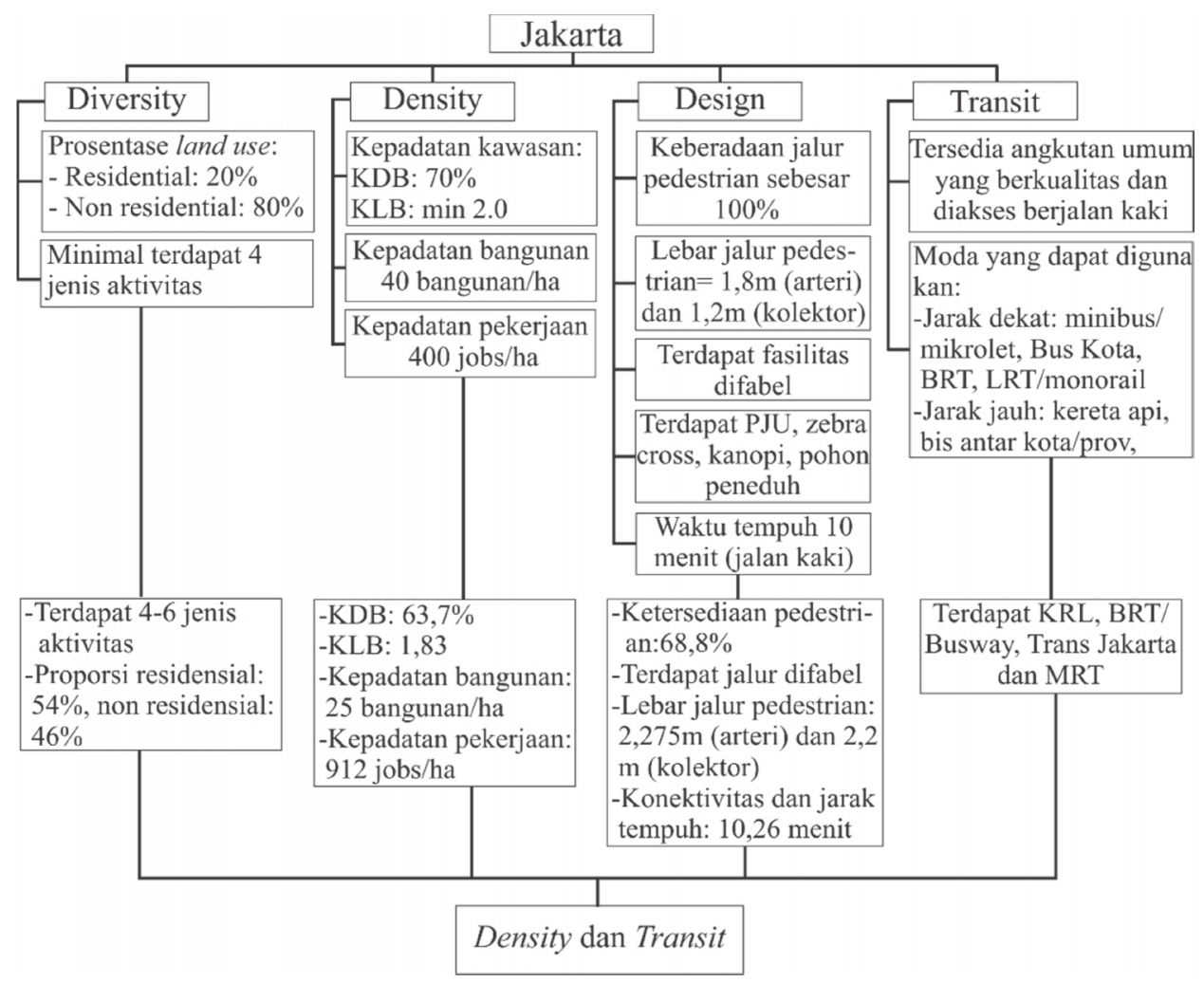

Gambar 5 Bagan Penerapan TOD di Kota Jakarta

Sumber: Penulis, 2019

Variabel diversity (keberagaman) dalam penerapan TOD di Kota Jakarta memiliki indikator yaitu prosentase land use dengan proporsi residensial $20 \%$ dan $80 \%$ non residensial serta minimal terdapat 4 jenis aktivitas. Pada kondisi eksisting kawasan transit di Kota Jakarta terdapat 4-6 jenis aktivitas dengan proporsi residensial 54\% dan non residensial 46\%. Variabel density (kepadatan) kawasan dengan indikator intensitas pemanfaatan lahan KDB $\geq 70 \%$ KLB min 2.0, kepadatan bangunan 40 bangunan/ha serta kepadatan pekerjaan 400 jobs/ha. Kawasan transit Blok M di Kota Jakarta memiliki KDB 
63,7\% dengan KLB 1,83, kepadatan bangunan 25 bangunan/ha serta kepadatan pekerjaan $910 \mathrm{jobs} / \mathrm{ha}$.

Variabel design (desain) kawasan memiliki indikator yang bertujuan untuk melihat kualitas dan kuantitas jalur pedestrian dengan adanya jalur pedestrian sebesar $100 \%$, lebar jalur pedestrian minimal 1,8m (arteri) dan 1,2m (kolektor), adanya jalur difabel, PJU, zebracross, kanopi, pohon peneduh, dan waktu tempuh 10 menit dengan berjalan kaki. Pada kondisi eksisting, kawasan transit Blok M memiliki ketersediaan jalur pedestrian dengan prosentase $68,8 \%$, adanya jalur difabel, lebar jalur pedestrian sebesar 2,275m (arter) dan 2,2m (kolektor) serta konektivitas dan jarak tempuh kawasan transit ke pusat kegiatan selama 10,26 menit. Pada variabel transit memiliki indikator tersedianya angkutan umum yang berkualitas dan dapat diakses dengan berjalan kaki. Kota Jakarta pada kondisi eksisting sudah memiliki berbagai macam moda tranportasi umum berupa KRL, BRT/Busway, Trans Jakarta dan MRT.

Penerapan konsep TOD di sekitar titik transit di Kota Jakarta, khususnya Blok M didominasi oleh variabel density (kepadatan kawasan) dan transit (angkutan umum), untuk selengkapnya dapat dilihat pada gambar berikut

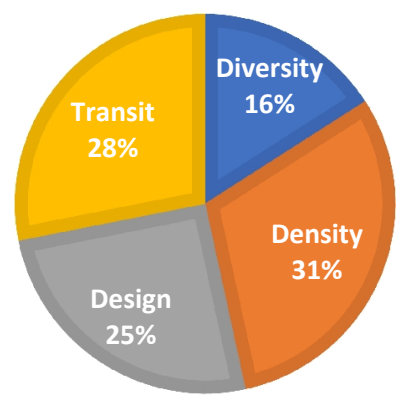

\section{Gambar 6 Diagram Prosentase Variabel TOD di Kota Jakarta \\ Sumber: Penulis, 2019}

Kota Jakarta pada kondisi eksisting memiliki kepadatan horizontal yang tinggi belum mengembangkan kepadatan vertikal namun pada pembangunannya terus mengalami improvisasi selain itu Kota Jakarta juga memiliki banyak titik transit berupa stasiun dan stasiun dengan berbagai macam moda transportasi yang melayaninya, yaitu KRT, BRT/Busway, Trans Jakarta serta MRT sehingga konsep TOD pada kawasan semakin terpenuhi. Pada variabel diversity (keberagaman penggunaan lahan) dan design (desain kawasan) pemerintah setempat juga terus melakukan perubahan yang positif karena TOD 
juga merupakan salah satu program pemerintah yang tercantum dalam RTRW DKI Jakarta sehingga kawasan transit di Kota Jakarta sendiri menjadi semakin ideal.

\subsection{Temuan Studi}

Berdasarkan studi kasus ditas, dirumuskan temuan studi yang selengkapnya dapat dilihat pada tabel berikut

Tabel 4 Temuan Studi Penelitian

\begin{tabular}{|c|c|c|c|c|}
\hline \multirow[b]{2}{*}{ Variabel } & \multicolumn{4}{|c|}{ Indikator } \\
\hline & Teori & $\begin{array}{c}\text { Studi Kasus } 1 \\
\text { (Kota Surabaya) }\end{array}$ & $\begin{array}{c}\text { Studi Kasus } 2 \\
\text { (Kota Bandung) }\end{array}$ & $\begin{array}{c}\text { Studi Kasus } 3 \\
\text { (Kota Jakarta) }\end{array}$ \\
\hline Diversity & \begin{tabular}{l}
\multicolumn{2}{c}{ Penggunaan } \\
lahan yang \\
bercampur (mixed \\
use) dan adanya \\
keberagaman \\
(diversity), dengan \\
komposisi \\
penggunaan \\
lahan: \\
- Publik: $10-15 \%$ \\
- Pusat \\
komersial/perk \\
antoran: 10- \\
40\% \\
- Permukiman: \\
50-80\% \\
Jenis kegiatan \\
yang tersedia pada \\
kawasan minimal \\
memiliki 4 jenis \\
kegiatan.
\end{tabular} & $\begin{array}{l}\text { Prosentase } \\
\text { penggunaan lahan: } \\
\text { - Residensial: } 30 \% \\
\text { - Non residensial: } \\
70 \% \\
\text { Minimal terdapat } 4 \\
\text { jenis penggunaan } \\
\text { lahan/jenis aktivitas }\end{array}$ & $\begin{array}{l}\text { Prosentase } \\
\text { penggunaan lahan: } \\
\text { a) Regional Center } \\
\text { - Residensial: } 20 \% \\
\text { - Non residensial: } \\
80 \% \\
\text { b) Urban Center } \\
\text { - Residensial: } 30 \% \\
\text { - Non residensial: } \\
70 \% \\
\text { Jumlah minimal } \\
\text { jenis penggunaan } \\
\text { lahan/jenis } \\
\text { aktivitas: } \\
\text { - Regional Center: } \\
\text { 5 jenis } \\
\text { - Urban Center: } 4 \\
\text { jenis }\end{array}$ & $\begin{array}{l}\text { Prosentase } \\
\text { penggunaan lahan: } \\
\text { - Residensial: } 20 \% \\
\text { - Non residensial: } \\
80 \% \\
\text { Minimal terdapat } \\
4 \text { jenis penggunaan } \\
\text { lahan/jenis aktivitas }\end{array}$ \\
\hline Density & \begin{tabular}{ll}
\multicolumn{2}{c}{ Kepadatan } \\
kawasan & \\
bangunan & dengan \\
fungsi & hunian \\
memiliki & \\
kepadatan & $>20$ \\
unit/ha. &
\end{tabular} & $\begin{array}{l}\text { Kepadatan } \\
\text { kawasan } \\
\text { - KDB minimal } 70 \% \\
\text { - KLB minimal } 2.0 \\
\text { - Kepadatan } \\
\text { bangunan: 100- } \\
1000 \text { bangunan/ha }\end{array}$ & $\begin{array}{l}\text { Kepadatan kawasan } \\
\text { pada: } \\
\text { a)Regional Center } \\
\text { - KDB: minimal } \\
80 \% \\
\text { - KLB minimal } 4 \\
\text { - FAR perkantoran } \\
\text { minimal } 2.0 \\
\text { b) Urban } \\
\text { Center } \\
\text { - KDB: minimal } \\
70 \% \\
\text { - KLB 1,5-3,5 } \\
\text { - FAR perkantoran } \\
\text { minimal 0,75 }\end{array}$ & $\begin{array}{l}\text { Kepadatan } \\
\text { kawasan } \\
\text { - KDB minimal } \\
70 \% \\
\text { - KLB minimal } 2.0 \\
\text { - Kepadatan } \\
\text { bangunan: } 40 \\
\text { bangunan/ha } \\
\text { - Kepadatan } \\
\text { pekerjaan: } \\
\text { 400jobs/ha }\end{array}$ \\
\hline Design & $\begin{array}{rr}\text { Lokasi } & \text { transit } \\
\text { sebaiknya } & \text { tidak } \\
\end{array}$ & $\begin{array}{l}\text { - Terdapat fasilitas } \\
\text { difabel }\end{array}$ & $\begin{array}{l}\text { - Terdapat fasilitas } \\
\text { difabel }\end{array}$ & $\begin{array}{l}\text { - Keberadaan jalur } \\
\text { pedestrian }\end{array}$ \\
\hline
\end{tabular}




\begin{tabular}{|c|c|c|c|c|}
\hline \multirow{3}{*}{ Variabel } & \multicolumn{4}{|c|}{ Indikator } \\
\hline & Teori & $\begin{array}{c}\text { Studi Kasus } 1 \\
\text { (Kota Surabaya) }\end{array}$ & $\begin{array}{c}\text { Studi Kasus } 2 \\
\text { (Kota Bandung) }\end{array}$ & $\begin{array}{c}\text { Studi Kasus } 3 \\
\text { (Kota Jakarta) }\end{array}$ \\
\hline & 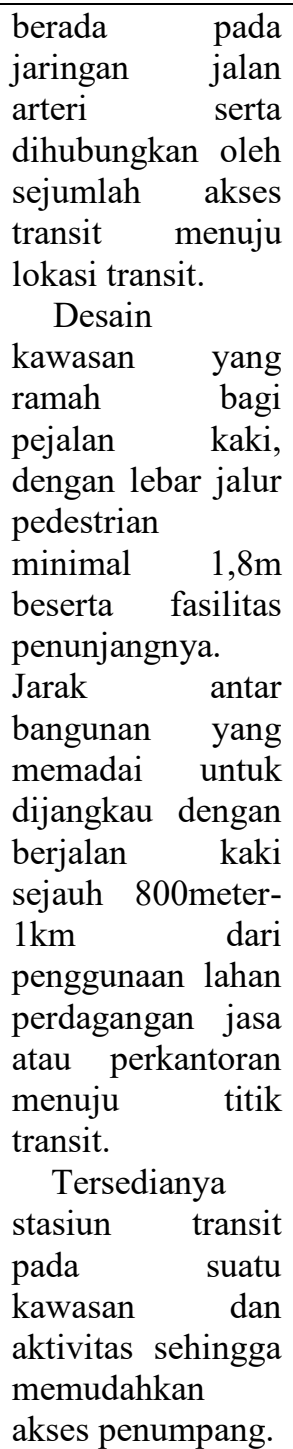 & $\begin{array}{l}\text { - } \text { Terdapat PJU } \\
\text { (Penerangan Jalan } \\
\text { Umum), } \\
\text { zebracross, kanopi } \\
\text { dan pohon peneduh } \\
\text { - Waktu tempuh } 10 \\
\text { menit dengan } \\
\text { berjalan kaki }\end{array}$ & $\begin{array}{l}\text { - Terdapat PJU, } \\
\text { zebracross, } \\
\text { kanopi dan pohon } \\
\text { peneduh } \\
\text { - Waktu tempuh } 10 \\
\text { menit dengan } \\
\text { berjalan kaki } \\
\text { - Adanya jalur } \\
\text { sepeda }\end{array}$ & 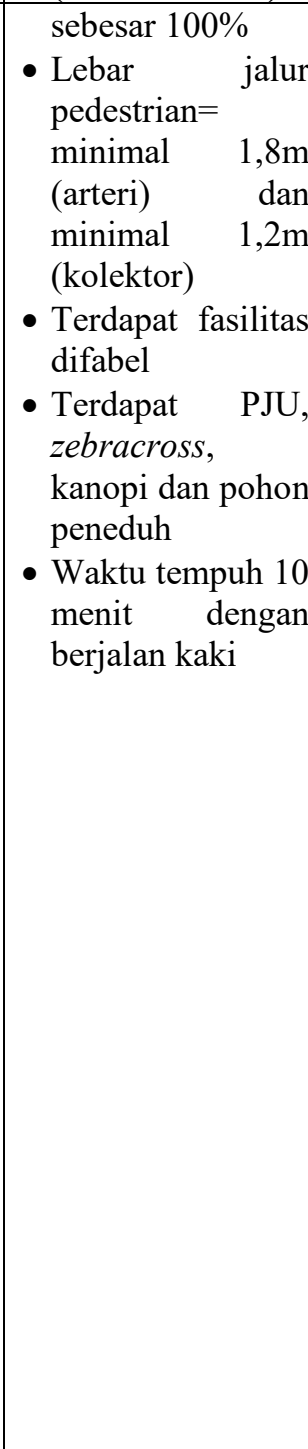 \\
\hline Transit & \begin{tabular}{l}
\multicolumn{1}{c}{ Tersedianya } \\
angkutan umum \\
massal yang \\
berkualitas tinggi \\
dan dapat diakses \\
dengan berjalan \\
kaki. \\
$\quad$ Moda yang \\
dapat digunakan: \\
- Commuter \& \\
$\quad$ Jarak Dekat: \\
Minibus/mikrol \\
et, Bis Kota, \\
BRT, \\
LRT/Monorel
\end{tabular} & \begin{tabular}{l}
\multicolumn{2}{c}{ Tersedianya } \\
angkutan umum \\
massal yang \\
berkualitas tinggi dan \\
terintegrasi. \\
Kriteria commuter \\
untuk jarak dekat: \\
- Minibus/mikrolet \\
- Bis kota \\
- BRT \\
- LRT/monorail \\
Untuk jarak jauh \\
(non commuter) \\
dapat menggunakan: \\
- Bis AKAP/AKDP
\end{tabular} & \begin{tabular}{l}
\multicolumn{2}{c}{ Tersedianya } \\
angkutan umum \\
massal yang \\
berkualitas tinggi \\
dan terintegrasi. \\
Kriteria \\
commuter untuk \\
jarak dekat: \\
- Minibus/mikrolet \\
- Bis kota \\
- BRT \\
- LRT/monorail \\
Untuk jarak jauh \\
(non commuter) \\
dapat
\end{tabular} & \begin{tabular}{|l}
\multicolumn{2}{c}{ Tersedianya } \\
angkutan umum \\
massal yang \\
berkualitas tinggi \\
dan terintegrasi. \\
Untuk regional \\
center dan urban \\
center memiliki \\
kriteria commuter \\
untuk jarak dekat: \\
- Minibus/mikrolet \\
- Bis kota \\
- BRT \\
- LRT/monorail \\
Untuk jarak jauh
\end{tabular} \\
\hline
\end{tabular}


Vol 24 No 1 Tahun 2019

\begin{tabular}{|l|l|l|l|l|}
\hline \multirow{3}{*}{ Variabel } & \multicolumn{4}{|c|}{ Indikator } \\
\cline { 2 - 5 } & \multicolumn{1}{|c|}{ Teori } & $\begin{array}{c}\text { Studi Kasus 1 } \\
\text { (Kota Surabaya) }\end{array}$ & $\begin{array}{c}\text { Studi Kasus 2 } \\
\text { (Kota Bandung) }\end{array}$ & \multicolumn{1}{|c|}{$\begin{array}{c}\text { Studi Kasus 3 } \\
\text { (Kota Jakarta) }\end{array}$} \\
\hline & $\begin{array}{l}\text { Non-commuter } \\
\text { Jarak Jauh: Bis }\end{array}$ & $\bullet$ Kereta Api & menggunakan: & $\begin{array}{l}\text { (non commuter) } \\
\text { dapat }\end{array}$ \\
& Antar & Bis & AKAP/AKDP & menggunakan: \\
& Kota/Prov, & & $\bullet$ Kereta Api & Bis \\
& Kereta Api & & & AKAP/AKDP \\
& & & & Kereta Api \\
\hline
\end{tabular}

Sumber: Penulis, 2019

Berdasarkan tabel diatas, dapat dilihat bahwa terdapat perbedaan antara indikator teori dan indikator studi kasus, dan masing-masing indikator pada studi kasus juga memiliki parameter yang berbeda pula. Dapat disimpulkan bahwa telah terjadi penyesuaian teori penerapan TOD di Indonesia, selain itu indikator penerapan TOD juga disesuaikan sesuai dengan karakteristik dan kebijakan kawasan tersebut sehingga terjadi perbedaan antara kawasan yang satu dengan yang lain

\subsection{Tantangan Pengembangan TOD}

Penerapan konsep Transit Oriented Development (TOD) pada beberapa kasus memiliki kekurangan atau tantangan dalam pengembangannya, berikut merupakan tantangan dalam penerapan pengembangan TOD pada masing-masing kasus:

\section{a. Kota Surabaya}

1. Penggunaan lahan non hunian masih didominasi di sekitar kawasan transit sehingga keberagaman kawasan masih sulit tercapai dan jarak antar aktivitas masih belum dapat dijangkau pejalan kaki

2. Kepadatan kawasan masih didominasi kepadatan horizontal sehingga aksesbilitas masyarakat terhadap fasilitas publik masih kurang dapat dicapai dengan berjalan kaki

3. Lahan yang telah dibebaskan dimanfaatkan bukan untuk pembuatan blok, pusat keberagaman aktivitas atau RTH namun dibuat untuk penambahan jalan raya

4. Masyarakat masih belum memiliki kebiasaan untuk berjalan kaki ataupun bersepeda

5. Belum tersedianya jalur pedestrian dan moda transportasi yang baik dan memenuhi secara kualitas dan kuantitas 


\section{b. Kota Bandung}

1. Kepadatan atau densitas kawasan masih cenderung horizontal belum kepadatan vertikal sehingga aksesbilitas masyarakat terhadap aktivitas publik masih belum dapat dijangkau dengan mudah

2. Pola perancangan kawasan masih menggunakan praktik zonasi yang memisahkan kawasan hunian, komersial, industri membuat masyarakat berjalan lebih jauh sehingga tidak ada ketertarikan untuk berjalan kaki

3. Penggunaan lahan di kawasan transit didominasi oleh penggunaan lahan hunian

4. Paradigma masyarakat yang masih memprioritaskan penggunaan kendaraaan pribadi dan membutuhkan waktu yang lama untuk memindahkan kebiasaan tersebut.

5. Penyediaan sistem transportasi secara kualitas dan kuantitas untuk mencapai transportasi yang berkelanjutan membutuhkan biaya yang besar dan waktu yang panjang

6. Pemerintah masih menyediakan parkir baik off street ataupun on street sehingga memungkinkan masyarakat masih menggunakan kendaraan pribadi

\section{c. Kota Jakarta}

1. Kemudahan dalam kredit kendaraan di perkotaan menyebabkan pertumbuhan jumlah kendaraan pribadi yang terus meningkat

2. Lansekap kawasan pengembangan TOD sebagian besar telah dipadati oleh permukiman. Perlu diadakan re-planning atau perencanaan kembali terkait perubahan penggunaan lahan dan kepadatan di sekitar kawasan transit yang memungkinkan adanya sengketa dari pemilik lahan dan bangunan pada lahan yang terkena perubahan

3. Pemahaman pengembangan TOD masih berorientasi pada pembangunan real estate atau hunian untuk kalangan elit bukan terkait konektivitas antar aktivitas

4. Pola perancangan kawasan masih menggunakan sistem zonasi yang memisahkan kawasan hunian, komersial, industri membuat masyarakat berjalan lebih jauh sehingga tidak ada ketertarikan untuk berjalan kaki

5. Besarnya biaya transportasi bagi orang-orang yang tinggal di Jakarta maupun sekitar Jakarta

6. Mahalnya lahan perkotaan, sehingga penyediaan fasilitas bagi pejalan kaki dan sepeda dianggap hal yang mewah. 


\section{KESIMPULAN DAN SARAN}

\subsection{Kesimpulan}

Transit Oriented Development (TOD) merupakan suatu konsep yang diciptakan untuk mengurangi kemacetan yang dapat memberikan landasan ekonomi, ekologi dan sosial untuk pembangunan regional (Calthorpe, 1993). Landasan ekonomi, ekologi dan sosial tersebut berkaitan dengan indikator transportasi berkelanjutan yang juga merupakan tujuan dari konsep TOD. Berdasarkan beberapa teori-teori menurut Calthorpe (1993), Cervero (1997), ITDP (2014) terkait variabel konsep TOD yaitu tersedianya terminal/stasiun, ruang publik/ruang terbuka, pusat perdagangan, pusat permukiman dan fasilitas umum, density (kepadatan), diversity (keberagaman), design (desain), berjalan kaki, bersepeda, saling terhubung, angkutan umum, percampuran penggunaan lahan, memadatkan, kekompakan kawasan, dan beralih atau beralihnya perilaku masyarakat dalam berkendara menjadi berjalan kaki. Berdasarkan teori-teori yang ada, variabel yang digunakan dalam penelitian ini merupakan variabel yang dicetuskan oleh Cervero (1997) yaitu Density, Diversity dan Design dan ITDP (2014) Transit (angkutan umum) karena variabel tersebut sudah menggambarkan seluruh prinsip utama dalam penerapan TOD secara lebih singkat.

Berdasarkan variabel-variabel yang telah ditemukan dan ditetapkan, yang dapat diambil dari tema studi kasus terkait penerapan TOD sebagai upaya mewujudkan transportasi yang berkelanjutan adalah Kota Surabaya didominasi oleh variabel transit, Kota Bandung didominasi oleh variabel density (kepadatan kawasan) dan transit (angkutan umum) dan Kota Jakarta didominasi oleh variabel density dan transit. Dari ketiga studi kasus, terdapat perbedaan antara indikator teori dan indikator studi kasus, dan masingmasing indikator pada studi kasus juga memiliki parameter yang berbeda pula. Dapat disimpulkan bahwa telah terjadi penyesuaian teori penerapan TOD di Indonesia, selain itu indikator penerapan TOD juga disesuaikan sesuai dengan karakteristik dan kebijakan kawasan tersebut sehingga terjadi perbedaan antara kawasan yang satu dengan yang lain.

\subsection{Saran}

Saran yang dapat diberikan terkait penerapan TOD sebagai upaya mewujudkan transportasi yang bekerlanjutan ditujukan oleh pemerintah dan untuk masyarakat pada masing-masing studi kasus, adalah sebagai berikut: 


\section{A. Bagi Pemerintah}

1. Pemerintah melakukan sosialisasi terarah dan efisien kepada masyarakat untuk menggunakan moda transportasi umum untuk mengurangi kemacetan, dampak lingkungan dan ekonomi masyarakat sehingga terwujudkan transportasi yang berkelanjutan

2. Perlu adanya monitoring dan evaluasi untuk penggunaan lahan, intensitas kawasan dan desain kawasannya

3. Perlu peningkatan jenis penggunaan lahan non residensial dan terpusat sehingga masyarakat mudah mengjangkaunya dengan berjalan kaki

4. Perlu peningkatan intensitas penggunaan lahan vertikal dan terintegrasi

5. Perlu peningkatan kualitas dan kuantitas jalur pedestrian yang aman, dan nyaman bagi pejalan kaki yang dilengkapi dengan fasilitas penunjangnya serta jalur difabel

6. Perlu peningkatan kualitas transportasi umum, sehingga masyarakat merasa nyaman dan mau menggunakannya

7. Pengurangan fasilitas-fasilitas yang memungkinkan penggunaan kendaraan pribadi seperti peningkatan biaya parkir atau peningkatan pajak kendaraan.

\section{B. Bagi Masyarakat}

1. Mulai beralih pada penggunaan moda transportasi umum yang telah disediakan oleh pemerintah untuk mengurangi kemacetan, permasalahan lingkungan dan ekonomi masyarakat terkait biaya transportasi

2. Menjaga kelestarian lingkungan, dengan berjalan kaki maupun bersepeda dalam melakukan aktivitas

3. Masyarakat aktif berkoordinasi dengan pemerintah untuk mengawasi dan menjaga kawasan agar lebih terawatt dan terjaga kualitasnya.

\section{DAFTAR PUSTAKA}

Peraturan Menteri ATR/BPN No. 16 Tahun 2017 tentang Pedoman Pengembangan Kawasan Berorientasi Transit

Alvinsyah. (2018). Penerapan Konsep TOD Sebagai Instrumen Penguatan Jaringan Angkutan Massal Perkotaan. Working paper IUTRI 04, Februari 2016

Arsyad, M. A., \& Handayeni, K. D. (2018). Pengukuran Kesesuaian Kawasan Transit Blok M Terhadap Kriteria Konsep TOD. Jurnal Teknik ITS Vol.7 No.1, 2337-3420. 
Azis, R., \& Asrul. (2014). Pengantar Sistem dan Perencanaan Transportasi. Yogyakarta: Deepublish.

Beela, K. (2007). Changing Definition of Sustainable Transportation. Retrieved from Enhr2007: www.enhr2007rotterdam.nl

BPS. (2017). Jakarta dalam Angka 2016. DKI Jakarta: Badan Pusat Statistik, 2016

BPS. (2016). Statistik Transportasi DKI Jakarta 2015-2016. DKI Jakarta: Badan Pusat Statistik. 2016

Brotodewo, N. (2010). Penilaian Indikator Transportasi Berkelanjutan Pada Kawasan Metropolitan di Indonesia. Jurnal Perencanaan Wilayah dan Kota, Vol.21 No.3, Desember, 165-182.

Calthorpe, P. (1993). The Next American Metropolis: Ecology, Community and The American Dreams. New York: Pricento Architectural Press.

Cervero, R. (2004). Transit Oriented Development in The United States: Experiences, Challenges, and Prospects. TCRP Report, Washington: Transportation Research Board, 102.

Dinas Perbuhungan Kota Bandung, 2013. Bandung Urban Mobility Project, Bandung.

Handayeni, K. D., \& Ariastita, P. G. (2014). Keberlanjutan Transportasi di Kota Surabaya Melalui Pengembangan Kawasan Berbasis TOD. Tata Loka Volume 16 Nomor 2, Mei, 108-115.

Huang, R., Grigolon, A., Madureira, M., \& Brussel, M. (2018). Measuring transit-oriented development (TOD) Network Complementarity Based on TOD Node Typology. The Journal of Transport and Land Use Vol. 11 No. 1, 304-324.

Hyungun, S., \& Ju Taek, O. (2011). Transit Oriented Development In A High-Density City: Identifying its Association With Transit Ridership in Seoul, Korea. The Korea Transport Institure, 2311 Daewha-dong, Ilsanseo-gu, Goyang-si, Gyeonggi-do 411701, Republic of Korea.

Isa, Muhammad Hidayat. 2016. Transit Oriented Develompent Sebagai Solusi Alternatif dalam Mengatasi Permaalahan Kemacetan di Kota Surabaya, dalam http://www.scribd.com, diunduh pada 6 Oktober 2018

Litman, T. (2003). Sustainable Transportation Indicators. Victoria Transport Policy.

Mauludy, M. F. (2019, April 21). Stasiun Hall Jadi Titik Simpul Sistem Angkutan Terintegrasi. Retrieved from Pikiran Rakyat: http://www.pikiran-rakyat.com

Mingqiao, Z., Lin, X., Mao, C., Zhang, K., \& Li, M. (2014). The Theory and Planning Principle of Transit Oriented Development. CICTP ASCE, 3532-3547.

Miro, F. (2012). Pengantar Sistem Transportasi. Jakarta: Erlangga.

Policy, I. f. (2014). TOD Standard. Retrieved from ITDP: https://www.itdp.org/wpcontent/uploads/2014/03/The-TOD-Standard-2.1.pdf 
Priadmadja, A., Anisa, \& Prayogi, L. (2017). Penerapan Konsep Transit Oriented Development (TOD) Pada Penataan Kawasan di Kota Tangerang. Jurnal Arsitektur PURWARUPA Volume 01 No.02 September 2017, 53-59.

Qodriyatun, S. N. (2012). Saatnya Beralih ke Sistem Transportasi Berkelanjutan. Jurnal Info Singkat Kesejahteraan Sosial Vol.IV, No.16/II/P3DI/Agustus, 9-12.

Ramadhani, Virta Safitri, \& Sardjito. (2017). Penentuan Prioritas Pengembangan Kawasan Transit Stasiun Gubeng dengan Konsep Transit Oriented Development. Jurnal Teknik ITS Vol.6, No.2, 481-485

Siregar, Deliani Poetriayu. (2015). Perencanaan Transit Oriented Development (TOD) Di Jakarta Pusat. Jurnal Arsitektur dan Perencanaan Vol.7 No.2 April 2014, 51-71

Tamin, O. (2007). Menuju Terciptakanya Sistem Transportasi Berkelanjutan di Kota-Kota Besar di Indonesia. Jurnal Transportasi Vol.7 No.2 Desember, 87-104.

The World Bank. (1996). Sustainable Transport: Priorities fo Policy Reform.

Widyahari, N. L., \& Indradjati, P. N. (2015). The Potential of Transid Oriented Development (TOD) and its opportunity in Bandung Metropolitan Area. Procedia Environmental Science 28, 474-482. 